\title{
Latest Developments in Continuous Glucose Monitoring, Insulin, and Adjunctive Treatments in Type 1 Diabetes
}

\author{
An expert interview with John B Buse
}

University of North Carolina, Chapel Hill, NC, US

DOl: https://doi.org/10.17925/USE.2018.14.2.54

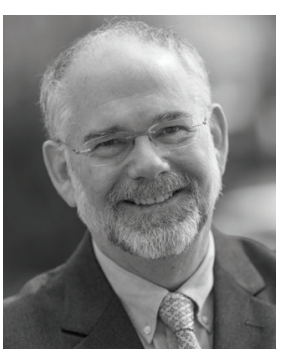

\begin{abstract}
John B Buse
John B Buse, MD, PhD, is the Verne S Caviness Distinguished Professor, Chief of the Division of Endocrinology, Director of the Diabetes Center, Director of the North Carolina (NC) Translational and Clinical Sciences Institute, and Executive Associate Dean for Clinical Research at the University of North Carolina (UNC) School of Medicine in Chapel Hill. He has been on the faculty at UNC since 1994 and has received international recognition for innovative patient-centered care. He works with teams of investigators in diabetes clinical trials, comparative effectiveness research, and translation of basic science towards clinical application. Dr Buse serves as Director of the NC Translational and Clinical Sciences Institute working through a National Institutes of Health (NIH)-based consortium to accelerate the conversion of ideas and discoveries to products and policies for the improvement of health and well-being. Dr Buse completed service as President for Medicine \& Science at the American Diabetes Association in 2008 and as Chair of the National Diabetes Education Program in 2014. He has received numerous awards and honors, including the 2010 Castle Connolly National Physician of the Year Award. He has authored more than 300 publications in journals including The New England Journal of Medicine, JAMA, and Diabetes Care. Dr Buse received his MD and PhD from Duke University before training in internal medicine and endocrinology at the University of Chicago.
\end{abstract}

\section{Keywords}

Continuous glucose monitoring, insulin therapy, type 1 diabetes

Disclosure: John B Buse's contracted consulting fees are paid to the University of North Carolina by Adocia, AstraZeneca, Dance Biopharm, Eli Lilly, MannKind, NovaTarg, Novo Nordisk, Senseonics, vTv Therapeutics, and Zafgen and he receives grant support from Novo Nordisk, Sanofi, and vTV Therapeutics. He is a consultant to Neurimmune AG. He holds stock options in Mellitus Health PhaseBio, and Stability Health. He is supported by a grant from the National Institutes of Health (UL1TR002489).

Acknowledgment: Medical writing assistance was provided by Katrina Mountfort of Touch Medical Media and was supported by Touch Medical Media.

Review Process: This is an expert interview and as such has not undergone the journal's usual peer review process but has been approved by the editorial board.

Authorship: The named author meets the Internationa Committee of Medical Journal Editors (ICMJE) criteria for authorship of this manuscript, takes responsibility for the integrity of the work as a whole, and has given final approval for the version to be published.

Open Access: This article is published under the Creative Commons Attribution Non-commercial License, which permits any non-commercial use, distribution, adaptation, and reproduction provided the original author and source are given appropriate credit. (c) The Author 2018.

Received: October 9, 2018

Published Online: November 14, 2018

Citation: US Endocrinology, 2018;14(2):54-5

Corresponding Author: John B Buse, 8025 Burnett Womack Building, Campus Box \# 7172 UNC-CH Chapel Hill, NC 27599-7170, US. E: jbuse@med.unc.edu

Support: No funding was received in

the publication of this article.
$\mathrm{T}$ ype 1 diabetes (T1D) is a substantial health burden worldwide, with approximately 1.35 million American children and adults living with T1D in 2015. ${ }^{1}$ Current guidelines from the American Diabetes Association (ADA) recommend an intensive insulin regimen for the treatment of T1D, ${ }^{2}$ on the basis of long-term clinical evidence. ${ }^{3}$ While the benefits of insulin are not disputed, the multiple injections and adverse effects result in a substantial treatment burden for patients. In particular, weight gain and the risk for hypoglycemia can cause increased comorbidities and poor compliance. ${ }^{4}$ While T1D is still associated with considerable premature mortality, there is reason for optimism, with a recent report of improved life expectancy in the US. ${ }^{5}$

In an expert interview, Dr Buse discusses recent advances in the management of T1D and their implications for clinical practice.

\section{Q. What have been the most significant recent developments in the area of continuous glucose monitoring in type 1 diabetes?}

Flash glucose monitors have been extremely popular among patients who don't want the burden of the alarms that are found in standard glucose monitors. They use the flash device many times a day, more than they would have used finger prick devices. I also think that the new DexCom G6 continuous glucose monitoring (CGM) system has the advantage of not requiring calibration. Some of my patients still feel the need to calibrate, which is fine, but they feel that the entire platform has been improved for them.

\section{Q. What are the limitations of insulin use in patients with type 1 diabetes?}

The management of T1D requires a patient to pay attention 24 hours a day, 365 days a year for the rest of their lives - a huge burden, and many patients feel that they need a break. Most patients do not achieve their glycated hemoglobin ( $\mathrm{HbA} 1 \mathrm{c}$ ) targets, sometimes because of lack of access to the highest quality care. Severe hypoglycemia is a major burden to patients with T1D and is a greater danger than the risk for blindness and renal failure, at least in the short term. Weight gain is a problem. Also, variable glucose values are experienced, which patients sense as a feeling of being unwell. People with T1D are doing much better today than they were 10-15 years ago, but we still haven't perfected the management of the condition. 


\section{Q. What adjunctive treatments to insulin are currently in use in type 1 diabetes?}

We now have devices such as insulin pumps and CGMs that are often linked together as low glucose suspend systems, or sensor-augmented pump therapy where much of the glucose management is done by the device with assistance from the patient.

With regards to medications beyond insulin, in the US we have pramlintide, which has to be injected with each meal. It is associated with modest improvements in HbA1c but also a modestly increased risk for severe hypoglycaemia. ${ }^{6}$ It has been noticed in the US that, over time, the effects tend to wane and many patients who have tried pramlintide do not continue in the long term.

A lot of work is being done on the sodium-glucose cotransporter (SGLT)-2 and SGLT-1/-2 inhibitors that shows substantial promise, with HDA1C reductions around $0.4 \%$, a trend towards reduced risk for hypoglycemia, weight loss, reduced glycemic variability, and blood pressure reductions. ${ }^{7-9}$ There is a small but significant increased risk for diabetic ketoacidosis and we need to learn how to mitigate that risk. The SGLT-inhibition process seems a very promising approach in T1D.

Some people believe that glucagon-like peptide 1 (GLP-1) receptor agonists could play a role in improving T1D care, but larger clinical trials haven't demonstrated consistent benefits and have had some suggestions of potential harm. Smaller studies have suggested benefits. ${ }^{10-12}$

A lot of small studies have been performed with metformin and sulfonylureas, thiazolidinediones, and alpha glucosidase inhibitors, which have provided no clear evidence of benefit but have suggested modest effects. ${ }^{13}$

\section{Q. What were the key findings of the inTandem1 and inTandem 2 studies of sotagliflozin in patients with type 1 diabetes?}

The inTandem 1 and inTandem2 studies are regulatory studies for patients with T1D who are inadequately controlled with insulin pumps or multiple daily injections. We studied the effects of two doses of sotagliflozin with $\mathrm{HbA} 1 \mathrm{C}$ as a primary endpoint. The average $\mathrm{HbA} 1 \mathrm{C}$ reduction was around $0.4 \%$ and this benefit was achieved with greater time in range by CGM, reduction in hypoglycemia, moderate reduction in weight (around 3-4 kg), and improvements in blood pressure. These were broad-based improvements in a variety of outcome measures that patients are interested in. Other patient-reported outcomes suggested a reduction in diabetes distress and a general sense of feeling better, most likely due to a decreased variability in glucose levels.?

\section{Q. Which other adjunctive therapies are being investigated for type 1 diabetes?}

Insulin pumps, CGM, and SGLT inhibitors are the areas of greatest research at present. There are some additional medications that are being evaluated. GLP-1 receptor agonists were in phase III development, particularly liraglutide, as discussed above, but that program has been suspended. ${ }^{14}$ There is a great deal of interest in preventing or delaying the progression of beta cell loss in T1D through a variety of immunotherapies and that work is ongoing. ${ }^{15}$ Islet replacement therapy in combination with tactics to prevent beta-cell destruction is the most nascent field. ${ }^{16}$

\section{Q. Which presentations/data have interested you most at this year's American Diabetes Association conference?}

There was a lot of information about pumps and sensors and their role in T1D. There were a number of presentations around the SGLT2 inhibitors. There was a relatively small study presented by Dr Dandona that suggested benefits from GLP-1 agonists. ${ }^{17}$

In type 2 diabetes (T2D) there are some upcoming disclosures that are very exciting and hopefully we will hear about them at the European Association for the Study of Diabetes meeting, but there have been some press releases suggesting a great deal of excitement around the SGLT2 inhibitors, in the setting of both T1D and T2D. This is a continuing area of ongoing investigation and the prognosis for patients with diabetes has never been better. $\square$
1. American Diabetes Association. Statistics about diabetes Available at: http://wwwdiabetesorg/diabetes-basics/statistics/ (accessed October 9, 2018).

2. American Diabetes Association. Standards of medical care in diabetes. Diabetes Care. 41:(Supp1).

3. Nathan DM. The diabetes control and complications trial/ epidemiology of diabetes interventions and complications study at 30 years: overview. Diabetes Care. 2014;37:9-16.

4. Farsaei S, Radfar M, Heydari Z, et al. Insulin adherence in patients with diabetes: risk factors for injection omission. Prim Care Diabetes. 2014;8:338-45.

5. Miller RG, Secrest AM, Sharma RK, et al. Improvements in the life expectancy of type 1 diabetes: the Pittsburgh Epidemiology of Diabetes Complications study cohort. Diabetes. 2012;61: 2987-92.

6. Ryan GJ, Jobe $\mathrm{J}$, Martin R. Pramlintide in the treatment of type 1 and type 2 diabetes mellitus. Clin Ther. 2005;27:1500-12.

7. Buse JB, Garg SK, Rosenstock J, et al. Sotagliflozin in combination with pptimized insulin therapy in adults with type 1 diabetes: the North American inTandem1 study. Diabetes Care. 2018;41:1970-80.
8. Mathieu C, Dandona P, Gillard P, et al. Efficacy and safety of dapagliflozin in patients with inadequately controlled type 1 diabetes (the DEPICT-2 study): 24-week results from a randomized controlled trial. Diabetes Care. 2018;41: 1938-46.

9. Dandona P, Matjhieu, C, Phillip M, et al. Long-term efficacy and safety of dapagliflozin in patients with inadequately controlled type 1 diabetes-the DEPICT-1 study. Diabetes. 2018;67(Suppl. 1) https://doi.org/10.2337/db18-119-LB

10. Mathieu C, Zinman B, Hemmingsson JU, et al. Efficacy and safety of liraglutide added to insulin treatment in type 1 diabetes: the ADJUNCT ONE treat-to-target randomized trial. Diabetes Care. 2016;39:1702-10

11. Ahren B, Hirsch IB, Pieber TR, et al. Efficacy and safety of liraglutide added to capped insulin treatment in subjects with type 1 diabetes: the ADJUNCT TWO randomized trial. Diabetes Care. 2016;39:1693-701.

12. Doggrell SA. Do glucagon-like peptide-1 receptor (GLP-1R) agonists have potential as adjuncts in the treatment of type 1 diabetes? Expert Opin Pharmacother. 2018;1-7.

13. Libman IM, Miller KM, DiMeglio LA, et al. Effect of metformin added to insulin on glycemic control among overweight/obese adolescents with type 1 diabetes: a randomized clinical trial. JAMA. 2015;314:2241-50

14. Novo Nordisk A/S. Novo Nordisk completes second and final phase 3a trial with liraglutide as adjunct therapy to insulin for people with type 1 diabetes (NN9211). 2015. Available at: https:// globenewswire.com/news-release/2015/08/24/762981/0/en/ Novo-Nordisk-completes-second-and-final-phase-3a-trial-withNovo-Nordisk-completes-second-and-final-phase-3a-trial-with-
liraglutide-as-adjunct-therapy-to-insulin-for-people-with-type-1 diabetes-NN9211.html (accessed October 9, 2018)

15. Smith EL, Peakman M. Peptide immunotherapy for type 1 diabetes-clinical advances. Front Immunol. 2018;9:392.

16. Castro-Gutierrez R, Michels AW, Russ HA. Beta cell replacement: improving on the design. Curr Opin Endocrinol Diabetes Obes. 2018:25:251-7.

17. Dandoner P, Ghanim $H$, Kuhadiya ND, et al. Liraglutide as an additional treatment to insulin in patients with type 1 diabetes mellitus-a 52-week randomized double-blinded placebocontrolled clinical trial. Presented at: American Diabetes Association 2018 Scientific Sessions, Orlando, FL, US, 24 June 2018, Abstract 3-LB. 